\title{
Analgesic and Anti-Inflammatory Effects of 80\% Methanol Extract of Leonotis ocymifolia (Burm.f.) Iwarsson Leaves in Rodent Models
}

\author{
Asnakech Alemu, ${ }^{1,2}$ Wondmagegn Tamiru $\left(\mathbb{D},{ }^{1}\right.$ \\ Teshome Nedi $(\mathbb{D})^{1}$ and Workineh Shibeshi $(\mathbb{D})^{1}$ \\ ${ }^{1}$ Department of Pharmacology and Clinical Pharmacy, School of Pharmacy, College of Health Sciences, \\ Addis Ababa University, Addis Ababa, Ethiopia \\ ${ }^{2}$ Food, Medicine and Healthcare Administration and Control Authority of Ethiopia (FMHACA), Addis Ababa, Ethiopia
}

Correspondence should be addressed to Wondmagegn Tamiru; mail2wondm@gmail.com

Received 26 October 2017; Revised 7 December 2017; Accepted 18 December 2017; Published 20 February 2018

Academic Editor: Junji Xu

Copyright (C) 2018 Asnakech Alemu et al. This is an open access article distributed under the Creative Commons Attribution License, which permits unrestricted use, distribution, and reproduction in any medium, provided the original work is properly cited.

\begin{abstract}
Background. Pain and inflammation are the major health problems commonly treated with traditional remedies mainly using medicinal plants. Leonotis ocymifolia is one of such medicinal plants used in folkloric medicine of Ethiopia. However, the plant has not been scientifically evaluated. The aim of this study was to evaluate analgesic and anti-inflammatory effects of the $80 \%$ methanol leaves extract of Leonotis ocymifolia using rodent models. Method. The central and peripheral analgesic effect of the extract at 100, 200 , and $400 \mathrm{mg} / \mathrm{kg}$ dose levels was evaluated using hot plate and acetic acid induced writhing rodent models, whereas carrageenan induced paw edema and cotton pellet granuloma methods were used to screen anti-inflammatory effect of the extract at the same dose levels. Acute toxicity test was also done. Data were analyzed using one-way ANOVA followed by Tukey's post hoc test and $p<0.05$ was considered significant. Results. The extract did not produce mortality up to $2000 \mathrm{mg} / \mathrm{kg}$. All tested doses of the extract showed significant analgesic effect with maximum latency response of $62.8 \%$ and inhibition of acetic acid induced writhing. Maximum anti-inflammatory effect was recorded at $6 \mathrm{~h}$ after induction, with $75.88 \%$ reduction in carrageenan induced paw edema. Moreover, all tested doses of extract significantly inhibited the formation of inflammatory exudates and granuloma formation $(p<0.001)$. Conclusion. The study indicated that the extract was safe in mice and it has both analgesic and anti-inflammatory effect in rodent models.
\end{abstract}

\section{Background}

Pain is an unpleasant sensory and emotional experience associated with actual or potential tissue damage. Mostly, it is considered as one of the signs and symptoms of an illness and the most common reason for patients' medical visit [1]. Inflammation is also the most common adaptive response of the body. Both pain and inflammation involve a complex array of biochemical processes such as enzyme activation, inflammatory mediator release and extravasation of fluid, cell migration, and tissue damage and repair [2].

Despite the availability of sufficient drugs, the side effects of analgesic and anti-inflammatory agents, which include gastrointestinal upset, gastric ulcer, bleeding, and liver damage, are a major concern in clinical use. Because of this, the search for safe and effective newer agents is growing. As one of research areas, screening medicinal plants with claimed analgesic and anti-inflammatory effect may create the opportunity of discovering new compounds with more safety and efficacy [3]. Traditionally, different practices are routinely used to manage pain and inflammation in various countries. Herbal remedies are widely used in developing countries to manage pain and inflammation because of their cost, accessibility, and eco-friendly advantages [4].

In Ethiopia, a large number of plant specious are traditionally used to treat ailments associated with pain like 
headache, stomachache, and wound. Very few of these plants have been scientifically evaluated while most of them remain unexplored $[3,5]$. The plant Leonotis ocymifolia (LO) belongs to the Lamiaceae family, also called Labiatae, and is characterized by a many-stemmed shrub, with average height of about $2.5 \mathrm{~m}[6,7]$. LO, locally known as Ras-kimir or Yeferes Zeng in Amharic [5], is indigenous to Eastern and Southern Africa [6].

Occasionally, it is used as an ascaricide and anticancer agent and as a remedy for ulcers and wounds. It is also reported that this plant is used in diabetes, hypertension, anemia, eczema, and other skin irritations [6]. It is also used for headache and ulcer of the neck [8], swelling [9], blackleg [10], hookworm, gout, and leishmaniasis. Moreover, it is reported to have antifertility [11] and antiemetic properties [12]. Moreover, the leaves of this plant are used to expel intestinal parasites from animals, particularly in the Bale Zone, Oromia region, Ethiopia $[9,13]$.

However, there were no studies so far investigating the use of LO for its analgesic and anti-inflammatory effects, although the plant is claimed to be used for this purpose by Ethiopian traditional healers $[6,8]$. Therefore, the aim of this study was to investigate the acclaimed analgesic and antiinflammatory effects of the leave extract of LO using various models in rodents.

\section{Methods}

2.1. Drugs and Chemicals. The drugs and chemicals used in the present study include carrageenan (Sigma Aldrich, Germany), aspirin and morphine (obtained from Ethiopian Pharmaceuticals Manufacturing), dexamethasone (Medico Labs, Lot E6A00, Syria), methanol (Carlo Erba, Italy), distilled water (Ethiopian Pharmaceuticals Manufacturing), Tween80 and ammonia (Loba Chemie, India), glacial acetic acid, chloroform, and sulfuric acid (Fisher Scientific, UK), acetic anhydride (Park Scientific, UK), picric acid (Sigma Aldrich, Germany), and ferric chloride solution (Finkem laboratory reagent, India).

2.2. Materials and Instruments. Rotary evaporator (Heidolph, Germany), lyophilizer (OPERON, OPR-FDU-5012, Korea), digital plethysmometer (Ugo Basile, Cat number 7140, Italy), electronic balance (KERN-ALJ 220-4, Germany), hot plate, mini orbital shaker (SSM1-STUART), and tissue Drying Oven (Medite-Medizintechnik, Germany).

2.3. Plant Material Collection and Authentication. In January 2017, the fresh leaves of LO were collected from East-Showa Zone of Ada'a District, Denkaka Kebele, Oromia region, Ethiopia. Identification and authentication of the plant specimen were done at the National Herbarium, Department of Plant Biology and Biodiversity Management, Addis Ababa University. A voucher specimen was deposited with voucher number AS 001/2017 for future reference.

2.4. Experimental Animals. Experimental animals were obtained from the animal house of toxicology department of EFMHACA and the animal house of School of Pharmacy, Addis Ababa University. Healthy Swiss albino mice, either sex weighing 25-35 g and aged 6-8 weeks, were used for analgesic and acute anti-inflammatory tests. In chronic anti-inflammatory model, male albino Wistar rats weighing $180-220 \mathrm{~g}$ were used, whereas only female mice were used for the acute toxicity study.

Animals were kept in plastic cages at room temperature and on a $12 \mathrm{~h}$ light-dark cycle with access to food pellet and water ad libitum. They were acclimatized to the laboratory condition for a week before the experiments. The Organization of Economic Corporation and Development (OECD) guideline 425/2008 for the Care and Handling of Animals was followed in all of the experimental procedures $[14,15]$.

2.5. Preparation of Plant Extracts. The leaves were washed gently by rinsing with distilled water gently to remove debris and dust particles. Then, the leaves of $\mathrm{LO}$ were air dried under shade and pulverized using a mortar and pestle to a coarse powder which was used for the extraction. 250 grams of LO leaf was used and macerated in $600 \mathrm{ml}$ of $80 \%$ methanol and the same volume of the solvent was used for successive extraction of the residues. To enhance the maceration process occasional shaking was carried out using mini orbital shaker with $120 \mathrm{rpm}$ for $72 \mathrm{hrs}$ at room temperature. Then, the extract was filtered first using muslin cloth and then using Whatman filter paper (number 1). Filtration and collection of the extract were done three times with the whole extraction taking 9 days. After the extraction, methanol was evaporated under vacuum using rotavapor at $40^{\circ} \mathrm{C}$. The resulting solution was placed in a deep freezer operating at $-20^{\circ} \mathrm{C}$ till it forms solid ice and then the remaining solvent (water) was removed using lyophilizer. After water removal, a light green black powder residue weighing $27.46 \mathrm{~g}$ was obtained, giving rise to a percentage yield of $11.44 \%$. The powder residue was then stored at $4^{\circ} \mathrm{C}$ until use. The extract was dissolved in $2 \%$ Tween- 80 in DW for the subsequent tests.

2.6. Acute Toxicity Study. Acute toxicity test was performed according to the OECD guideline 425/2008. Fasted female albino mice of 6-8 weeks were used for the toxicity study. First, a sighting study was performed to determine the starting dose, in which a single female mouse was given $2000 \mathrm{mg} / \mathrm{kg}$ of the extract as a single dose by oral gavage. Since no death was observed within $24 \mathrm{~h}$, additional four mice were recruited for the extract treatment at the same dose. The animals were observed continuously in the first $4 \mathrm{~h}$ with $30 \mathrm{~min}$ interval and then for 14 consecutive days with an interval of $24 \mathrm{~h}$ for the general signs and symptoms of toxicities. These signs and symptoms include changes in skin, eyes, mucous membranes, somatomotor activity, behavioral pattern, salivation, diarrhea, weight loss, tremor, convulsions, lethargy, paralysis, food and water intake, and mortality. Based on the results of the acute toxicity test, three treatment doses of the extract were chosen: a middle dose, which was one-tenth of the maximum dose obtained during acute toxicity study; a low dose, which was half of the middle dose; and a high dose which was twice the middle dose. 


\subsection{Evaluation of Analgesic Activity of the Extract}

2.7.1. Acetic Acid Induced Writhing Method. The method of Arul et al. was used with slight modification [16]. Mice of either sex were divided into five groups with each consisting of six animals. Three groups were given different dose of the plant extract, while the control group was given a vehicle and the reference group was given $150 \mathrm{mg} / \mathrm{kg}$ of aspirin just one hour before $0.6 \%$ acetic acid $(10 \mathrm{ml} / \mathrm{kg}$, i.p.) administration [17]. Five minutes after the acetic acid injection i.p., the number of writhes was counted to determine analgesic activity of LO. The animals were placed in a glass jar individually and the contractions of abdominal muscles together with stretching of the hind limbs were cumulatively counted over a period of 30 minutes.

The percentage protection against writhing was taken as an index of analgesia $[17,18]$ and calculated using the following formula:

$$
\begin{aligned}
& \% \text { Analgesic Activity } \\
& =\frac{\text { Mean writhing count (control group }- \text { Treated group) }}{\text { Mean writhing count of control group }} \\
& \quad \times 100 .
\end{aligned}
$$

2.7.2. Hot Plate Method. This test consists of introducing a mouse into an open-ended cylindrical space with a floor consisting of a metallic plate which is heated at a constant temperature. This produces two behavioral components, which are measured in terms of their reaction times, namely, paw licking and jumping. These responses are considered to be supraspinally integrated [18]. Mice of either sex were divided into five groups, each consisting of six animals. All animals were fasted overnight. Three groups were given different doses of the plant extract (determined based on acute toxicity, p.o.), while one group was given a vehicle (control, p.o.) and the other group was given standard drug morphine (reference group, $20 \mathrm{mg} / \mathrm{kg}$ oral). The animals were placed on a hot plate maintained at a temperature of $55 \pm 1^{\circ} \mathrm{C}$ [19]. Before the treatment, the reaction time of each animal was recorded. The latency to lick the paw or jump from the hot plate was noted as the reaction time. The reaction times were noted at 30,60, 90, and $120 \mathrm{~min}$. The cut-off time was considered as $15 \mathrm{~s}$ [20].

Percentage increase in reaction time or pain threshold inhibition was derived, using the formula [21]

$$
\begin{aligned}
\% \text { Elongation }= & \frac{\text { Latency }(\text { test })-\text { Latency }(\text { control })}{\text { Letency }(\text { test })} \\
& \times 100 .
\end{aligned}
$$

\subsection{Evaluation of Anti-Inflammatory Activity of the Extract}

2.8.1. Carrageenan Induced Mice Paw Edema. The acute antiinflammatory activity of the extract was determined in mice according to the method of Winter et al. [22]. Mice were fasted for $12 \mathrm{~h}$ with free access to water until the experiment starts. Acute inflammation was produced by injection of carrageenan $(1 \% \mathrm{w} / \mathrm{v}$ carrageenan in normal saline, $50 \mu \mathrm{l})$ in the right hind paw of the mice. Carrageenan was injected one hour after oral administration of the extract [23]. The inflammation was quantitated in terms of $\mathrm{ml}$, that is, displacement of water by edema using a digital plethysmometer at times $0,1,2,3,4,5$, and $6 \mathrm{~h}$ after carrageenan injection [24]. The percent inhibition of edema was calculated in comparison to the control animals and was calculated using the following formula [25]:

$$
\% \text { inhibition }=\frac{\text { Mean paw volume }(\text { control group })-\text { Mean paw volume }(\text { treated group })}{\text { Mean paw volume }(\text { control group })} \times 100 \text {. }
$$

2.8.2. Cotton Pellet Induced Granuloma Method. The method previously described by Meier et al. [26] was used with some modifications to assess the transudative and proliferative (granulomatous) components of chronic inflammation. Male albino Wistar rats (180-220 g) were fasted for $12 \mathrm{~h}$ with free access to water until commencement of the experiment. The control, reference, and test groups of rats received $2 \%$ Tween-80, dexamethasone ( $0.5 \mathrm{mg} / \mathrm{kg}$ p.o.) [27], and extracts, respectively.

Sterile cotton pellet weighing $10 \pm 1 \mathrm{mg}$ was prepared by rolling of a cotton piece of $10 \mathrm{mg}$ and sterilized by autoclaving for $30 \mathrm{~min}$ at $120^{\circ} \mathrm{C}$ under $15 \mathrm{lbs}$ pressure. Twenty minutes after treatment with the reference drug and extracts, the rats were anesthetized with diethyl ether and subcutaneous tunnel was made aseptically using blunted forceps in both sides of previously shaved groin region of each rat. Two sterilized cotton pellets weighing $10 \pm 1 \mathrm{mg}$ each were then implanted bilaterally in the subcutaneous tunnel and sutured with chromic catgut (0/4 metric- $1 / 2$ circle). Treatment with the reference drug (dexamethasone) and extracts continued for seven consecutive days (p.o., once a day). On the 8th day, the rats were sacrificed with diethyl ether anesthesia; thereafter, the pellets surrounded by granuloma tissue were dissected out carefully and freed from extraneous tissue. The wet weight of the cotton was taken immediately after removal and then dried at $60^{\circ} \mathrm{C}$ for $24 \mathrm{hrs}$ and the net dry weight, that is, after subtracting the weight of the cotton pellets, was determined.

The exudate amount (mg), granulation tissue formation (mg), and percent inhibition of exudate and granuloma tissue formation were calculated according to the formula given below [28]:

$$
\begin{aligned}
& \text { Exudates inhibition (\%) } \\
& =1-\frac{\text { Exudates in treated group }}{\text { Exudates in control group }} \times 100,
\end{aligned}
$$


Granuloma inhibition (\%)

$$
=1-\frac{\text { Granuloma in Treated group }}{\text { Exudates in control group }} \times 100,
$$

where

$$
\begin{aligned}
& \text { Measure of Exudates } \\
& \text { = immediate wet weight of pellet } \\
& \quad \text { - Constant dry weight of pellet, }
\end{aligned}
$$

Measure of granuloma

$$
\begin{aligned}
= & \text { Constant dry weight of cotton } \\
& - \text { Initial weight of cotton pellet. }
\end{aligned}
$$

2.9. Preliminary Phytochemical Screening. Phytochemical screening was carried out to confirm the presence or absence of secondary metabolites, which may be responsible for analgesic and anti-inflammatory effect, such as alkaloids, steroidal compounds, phenolic compounds, tannins, saponins, flavonoids, cardiac glycosides, and anthraquinones using standard procedures as stated in Trease and Evans as well as Abraham et al. [29, 30].

2.10. Statistical Analysis. The data were analyzed using SPSS version 20.0 for Windows. The experimental results are expressed as mean \pm standard error of the mean (SEM) and statistical analysis was carried out using one-way analysis of variance (ANOVA) followed by Tukey's post hoc test for multiple comparisons among treatment groups. $p$ value < 0.05 was considered statistically significant at $95 \%$ confidence interval. The analyzed data were then presented using tables. Linear regression was also used to determine dose-response relationships.

\section{Results}

3.1. Acute Toxicity Study. The acute oral toxicity test of $80 \%$ methanolic leaf extract $(80 \mathrm{ME})$ of $\mathrm{LO}$ at the limit dose of $2000 \mathrm{mg} / \mathrm{kg}$ did not show gross behavioral changes, toxic effects, or mortality within the $24 \mathrm{~h}$ and the 14 days of observation. Therefore, the oral $\mathrm{LD}_{50}$ of crude $80 \mathrm{ME}$ is greater than $2000 \mathrm{mg} / \mathrm{kg}$ in mice based on OECD 425/2008 guideline [15]. Hence, the result suggests that the extract is safe.

\subsection{Analgesic Activity}

3.2.1. Acetic Acid Induced Writhing Assay. All test doses of the extract significantly $(p<0.001)$ reduced the acetic acid induced writhing in mice. Compared to the lower doses of the plant extract, the $400 \mathrm{mg} / \mathrm{kg}$ dose of LO (LO400) showed analgesic effect against acetic acid induced writhing response in mice $(p<0.001)$. Aspirin $(150 \mathrm{mg} / \mathrm{kg})$ also showed a potent analgesic effect $(p<0.001)$ compared to the $100 \mathrm{mg} / \mathrm{kg}$ and $200 \mathrm{mg} / \mathrm{kg}$ dose of the extracts. However, the LO400 has a comparable analgesic effect with that of aspirin.

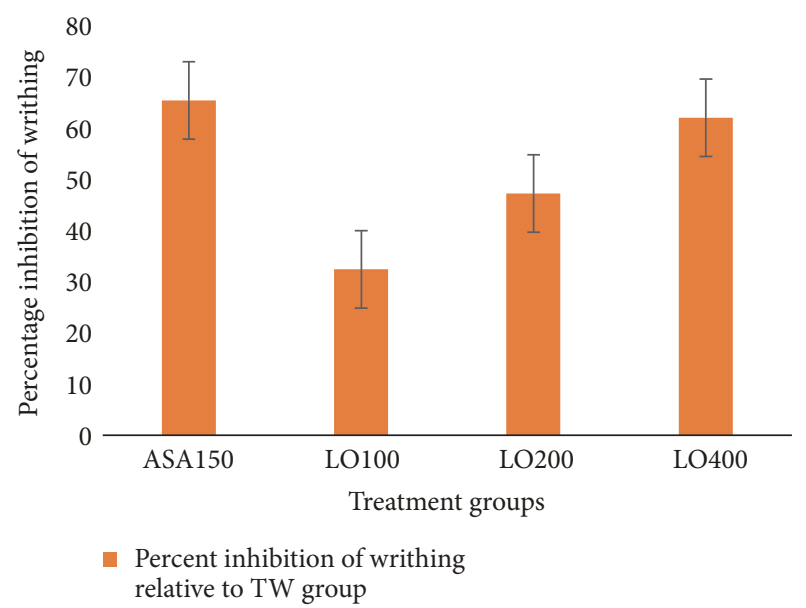

Figure 1: Percentage inhibition of $80 \%$ methanol leaf extract of Leonotis ocymifolia on acetic acid induced writhing model in mice. TW $(10 \mathrm{ml} / \mathrm{kg}) ; \mathrm{ASA}$, aspirin $(150 \mathrm{mg} / \mathrm{kg}) ; \mathrm{LO} 100$, extract $(100 \mathrm{mg} / \mathrm{kg}) ; \mathrm{LO} 200$, extract $(200 \mathrm{mg} / \mathrm{kg})$; LO400, extract (400 mg/kg).

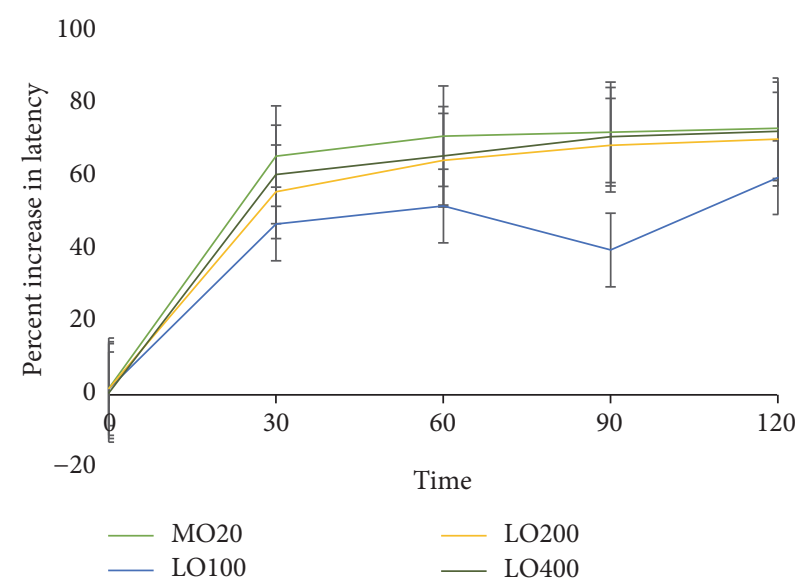

Figure 2: Percentage increase in latency time of $80 \%$ methanol extracts of Leonotis ocymifolia relative to negative control (TW) based on hot plate method latency time in mice. TW, Tween80 (2\%); MO, morphine (20 mg/kg); LO100, extract $(100 \mathrm{mg} / \mathrm{kg})$; LO200, extract (200 mg/kg); LO400, extract ( $400 \mathrm{mg} / \mathrm{kg})$.

The $80 \%$ methanol extract of LO produced a significant $(p<0.001)$ analgesic effect against acetic acid induced writhing at the dose of 100,200 , and $400 \mathrm{mg} / \mathrm{kg}$; the inhibitions were $32.8 \%, 47.9 \%$, and $62.8 \%$ (Figure 1). Moreover, this effect of the extract was in dose dependent manner $\left(R^{2}=\right.$ 0.8628).

3.2.2. Hot Plate Assay. The LO extract significantly $(p<$ 0.001 ) delayed the reaction time of mice to hot plate thermal stimulation at all dose levels with maximum effect at $120 \mathrm{~min}$ (Figure 2). LO400 and morphine produced a comparable maximum analgesic effect at $120 \mathrm{~min}(72.84 \%)$. The percent inhibition of 100,200 , and $400 \mathrm{mg} / \mathrm{kg}$ of LO was $59.3 \%$, $69.9 \%$, and $72.0 \%$, respectively, at the $120 \mathrm{~min}$ point in dose dependent manner $\left(R^{2}=0.872\right)$. Intergroup comparison 


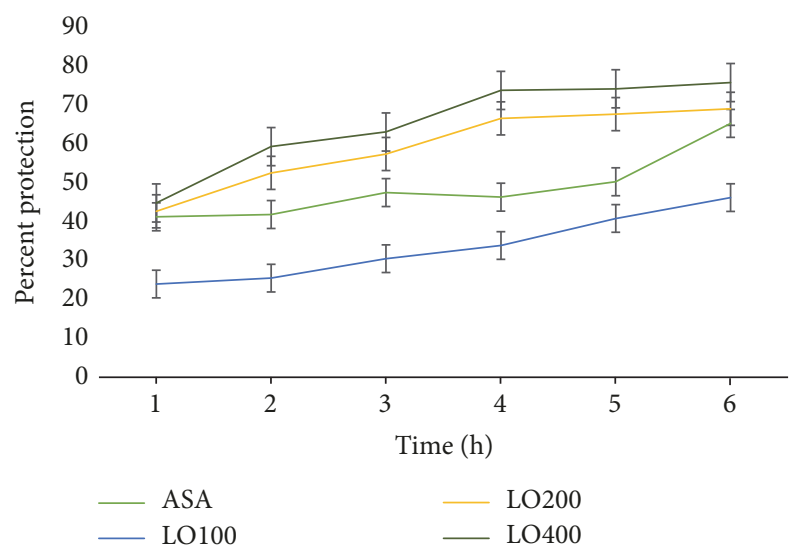

FIGURE 3: Percentage inhibition of $80 \%$ methanol extract of Leonotis ocymifolia on carrageenan induced paw edema model in mice. ASA, aspirin $100 \mathrm{mg} / \mathrm{kg}$; LO100, extract (100 mg/kg); LO200, extract (200 mg/kg); LO400, extract (400 mg/kg).

demonstrated that a significant delay in the response to the hot plate thermal stimulation was observed in the $200 \mathrm{mg} / \mathrm{kg}$ compared with $100 \mathrm{mg} / \mathrm{kg}$ ( $p<0.001$ from $30 \mathrm{~min}$ to $120 \mathrm{~min}$ ), the 400 relative to $100 \mathrm{mg} / \mathrm{kg}$ ( $p<0.001$ from $30 \mathrm{~min}-120 \mathrm{~min}$ ), whereas the $20 \mathrm{mg} / \mathrm{kg}$ morphine demonstrated potent analgesic effect compared with the $400 \mathrm{mg} / \mathrm{kg}$ ( $p<0.001$ from $30 \mathrm{~min}$ to $90 \mathrm{~min}$ and $p<0.05$ at $120 \mathrm{~min}$ ).

\subsection{Anti-Inflammatory Activity}

3.3.1. Carrageenan Induced Paw Edema. All test doses of the ME80 showed a significant $(p<0.001)$ inhibition of paw edema from the 1st to the 6th h after induction $(p<0.001)$. The maximum anti-inflammatory effect of $\mathrm{LO}$ was observed at $6 \mathrm{~h}$ after induction at all doses, following a trend shown in Figure 3, with $46.3 \%, 69.13 \%$, and $75.88 \%$ inhibition in dose dependent manner $\left(R^{2}=0.916\right)$. Intergroup comparison revealed that LO200 and LO400 got a comparable antiinflammatory effect than the LO100, even higher than aspirin $(150 \mathrm{mg} / \mathrm{kg})$, throughout the observation period. However, aspirin has a comparable anti-inflammatory effect as that of LO100.

3.3.2. Cotton Pellet Induced Granuloma. The ME80 of LO significantly $(p<0.001)$ prevented the formation of inflammatory exudates and granuloma mass at all tested doses. Intergroup comparisons revealed that the LO400 is relatively superior to the LO200 and LO100 in both exudate and granuloma inhibition (with $p$ value ranging from $<0.05$ to $<0.001)$. Furthermore, the anti-inflammatory effect of the LO was in dose dependent fashion $\left(R^{2}=0.558\right)$.

On the other hand, $28.91 \%, 37.68 \%$, and $45.91 \%$ inhibition of inflammatory exudate and $24.03 \%, 40.18 \%$, and $50.65 \%$ reduction of granuloma were recorded at $100 \mathrm{mg} / \mathrm{kg}$, $200 \mathrm{mg} / \mathrm{kg}$, and $400 \mathrm{mg} / \mathrm{kg}$ doses, respectively, while, dexamethasone showed $52.89 \%$ and $79.54 \%$ inhibition of exudates and granuloma, respectively (Figure 4 ).

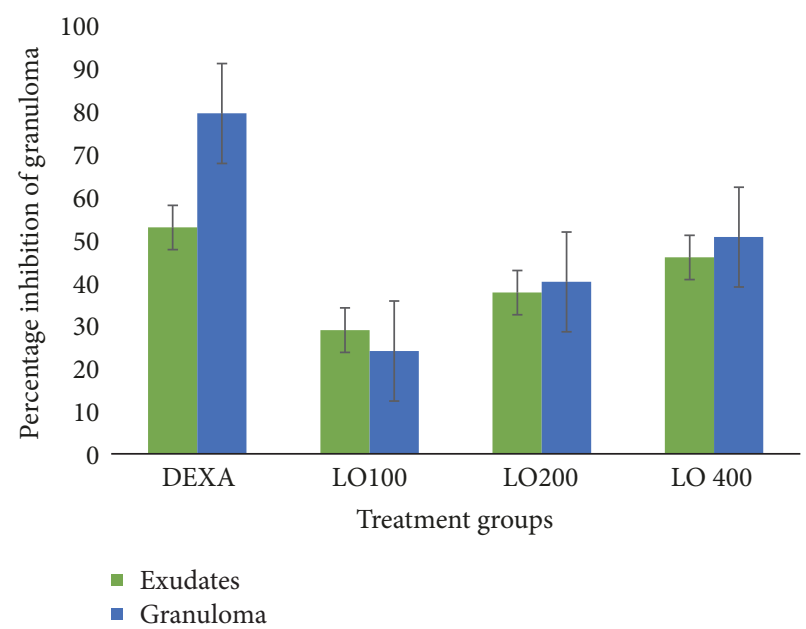

FIgURE 4: Percentage inhibition of $80 \%$ methanol extract of Leonotis ocymifolia on cotton pellet induced granuloma model in rats. Data is expressed as mean $\pm \mathrm{SEM}, n=6$; TW, $2 \%$ Tween- $80(10 \mathrm{ml} / \mathrm{kg})$; dexamethasone $(0.5 \mathrm{mg} / \mathrm{kg}) ; \mathrm{LO} 100$, extract $(100 \mathrm{mg} / \mathrm{kg}) ; \mathrm{LO} 200$, extract $(200 \mathrm{mg} / \mathrm{kg}) ; \mathrm{LO} 400$, extract $(400 \mathrm{mg} / \mathrm{kg})$.

3.3.3. Phytochemical Screening. Preliminary chemical screening of aqueous extract of the leaves of $\mathrm{LO}$ showed the presence of saponins, alkaloids, flavonoids, tannins, terpenoids, and phenols.

\section{Discussion}

Leonotis ocymifolia is a folkloric herbal medicine which has been used for the treatment of pain and inflammation in Ethiopia [9]. However, its pharmacological analgesic and anti-inflammatory effects have not been scientifically validated. Therefore, the aim of the present study was to investigate the analgesic and anti-inflammatory effects of the $80 \%$ methanol extract of LO rodent models.

The LO effectively inhibited acetic acid induced pain. Acetic acid induced writhing mice model is used to study the peripheral analgesic activity of test substances. The inflammatory pain in this model is induced by capillary permeability and reduced nociceptive threshold because of stimulation of nociceptive fibers of the nervous terminal [31]. It may also induce pain by increasing the release of $\mathrm{PGE}_{2}$ and $\mathrm{PGF}_{2 \alpha}$ at the peritoneal receptors $[32,33]$. Thus, the analgesic effect of LO may be due to interference of these nociceptive targets. On the other hand, LO delayed the latency time for hot plate model. This model, which relies on nociceptive reaction against thermal stimuli, is well-established for detection of opiate (narcotic) analgesic property for centrally acting analgesics [34]. Therefore, the result may suggest that the extract may also have a central analgesic effect.

In carrageenan induced model, LO reversed carrageenan induced inflammation and swelling. This experimental model was employed to evaluate the effect of the extract on acute inflammation [32,35]. Carrageenan is an agent of choice for testing anti-inflammatory drugs since it is devoid of antigenic reaction and systemic effects with high 
degree of reproducibility [36]. It involves a biphasic release of various types of chemical mediators of inflammation such as histamine, serotonin, bradykinin, and prostaglandins, which cause pain and fever [36-38]. Thus, the anti-inflammatory effect of LO may involve interferences on such processes, particularly at the later stage.

However, the cotton pellet induced granuloma model was used to test the effect of the extract in chronic inflammation [39]. This model is commonly used to assess the transudative and proliferative components of chronic inflammation $[32,40]$. The weight of wet cotton pellets correlates with exudative material and the weight of dry pellets correlates with the amount of granulomatous tissue [41]. Based on the findings, LO effectively inhibited granuloma formation, which indicates its effect against chronic inflammation.

Plants which have analgesic and anti-inflammatory activity contain mainly alkaloids, flavonoids, saponin, tannins phenolic compound, glycosides, coumarins, and triterpenoids chemical constituents [42-45]. Tannins, flavonoids, and saponins are well known for their ability to inhibit pain perception and anti-inflammatory properties due to inhibition of enzymes involved in inflammation, especially arachidonic acid metabolic pathway, and synthesis of prostaglandins $[46,47]$. Tannins could affect the inflammatory response via free radical scavenging properties and inhibition of iNOS in macrophages [48]. Saponins, on the other hand, inhibit pain and inflammation via NO inhibition [49, 50]. Therefore, the presence of saponins, alkaloids, flavonoids, tannins, terpenoids, and phenols may be responsible for the analgesic and anti-inflammatory effects of LO.

\section{Conclusion}

The present study indicated that the $80 \%$ methanol leaf extract of Leonotis ocymifolia is safe in mice. In addition, it has both analgesic and anti-inflammatory activities in rodent models. The presence of saponins, alkaloids, flavonoids, tannins, terpenoids, and phenolic compounds was also confirmed in the extract.

\section{Data Availability}

The datasets used and/or analyzed during the current study are available from the corresponding author on reasonable request.

\section{Ethical Approval}

All procedures complied with the Guide for the Care and Use of Laboratory Animals and OECD guideline 425 for acute toxicity. The Institutional Review Board of the School of Pharmacy approved the procedures and approved the ethical clearance.

\section{Conflicts of Interest}

The authors declare that they have no conflicts of interest.

\section{Authors' Contributions}

Asnakech Alemu, Teshome Nedi, and Workineh Shibeshi conceived and designed the research. Asnakech Alemu conducted the experiments. Asnakech Alemu, Workineh Shibeshi, Teshome Nedi, and Wondmagegn Tamiru completed the statistical analysis and manuscript write-up. All authors read the manuscript and contributed their part before submission of the manuscript.

\section{Acknowledgments}

The authors are very grateful to Addis Ababa University for funding this study and Ethiopian Food, Medicine and Healthcare Administration and Control Authority for funding and providing chemicals as well as the Ethiopian Pharmaceuticals Manufacturing (EPHARM) for providing chemicals.

\section{References}

[1] K. H. Kumar and P. Elavarasi, "Definition of pain and classification of pain disorders," Journal of Advanced Clinical \& Research Insights, vol. 3, pp. 87-90, 2016.

[2] R. Medzhitov, "Origin and physiological roles of inflammation," Nature, vol. 454, no. 7203, pp. 428-435, 2008.

[3] H. Geremew, W. Shibeshi, W. Tamiru, and E. Engdawork, "Experimental evaluation of analgesic and anti-inflammatory activity of $80 \%$ methanolic leaf extract of Moringa stenopetala Bak. F. in mice," Ethiopian Pharmaceutical Journal, vol. 31, no. 1, 2015.

[4] H. M. A. Ullah, S. Zaman, F. Juhara et al., "Evaluation of antinociceptive, in-vivo \& in-vitro anti-inflammatory activity of ethanolic extract of Curcuma zedoaria rhizome," BMC Complementary and Alternative Medicine, vol. 14, no. 346, 2014.

[5] A. Alemu, Evaluation of the in vivo analgesic and anti-inflammatory activities of $80 \%$ methanol extract of Leonotis ocymifolia (Burm. F.) Iwarsson leaves, AAU, 2017.

[6] A. Yeshitila, Phytochemical investigation on the leaves of leonotis ocymifolia, AAU, 2006.

[7] K. Vagionas, K. Graikou, I. B. Chinou, D. Runyoro, and O. Ngassapa, "Chemical analysis and antimicrobial activity of essential oils from the aromatic plants artemisia afra jacq. and leonotis ocymifolia (Burm. F.) iwarsson var. raineriana (visionl) Iwarsson growing in Tanzania," Journal of Essential Oil Research, vol. 19, no. 4, pp. 396-400, 2007.

[8] E. d'Avigdor, H. Wohlmuth, Z. Asfaw, and T. Awas, "The current status of knowledge of herbal medicine and medicinal plants in Fiche, Ethiopia," Journal of Ethnobiology and Ethnomedicine, vol. 10, no. 1, pp. 38-71, 2014.

[9] H. Yineger, E. Kelbessa, T. Bekele, and E. Lulekal, "Ethnoveterinary medicinal plants at Bale Mountains National Park, Ethiopia," Journal of Ethnopharmacology, vol. 112, no. 1, pp. 5570, 2007.

[10] E. Lulekal, Z. Asfaw, E. Kelbessa, and P. Van Damme, "Ethnoveterinary plants of Ankober District, North Shewa Zone, Amhara Region, Ethiopia," Journal of Ethnobiology and Ethnomedicine, vol. 10, no. 1, article no. 21, 2014.

[11] G. Tafesse, Y. Mekonnen, and E. Makonnen, "In vivo and in vitro anti-fertility and anti-implantation properties of Leonotis ocymfolia in rats," African Journal of Traditional, Complementary and Alternative Medicines, vol. 2, pp. 103-112, 2006. 
[12] E. Lulekal, Z. Asfaw, E. Kelbessa, and P. Van Damme, "Ethnomedicinal study of plants used for human ailments in Ankober District, North Shewa Zone, Amhara Region, Ethiopia," Journal of Ethnobiology and Ethnomedicine, vol. 9, article 63, 2013.

[13] A. Kefalew, Z. Asfaw, and E. Kelbessa, "Ethnobotany of medicinal plants in Ada'a District, East Shewa Zone of Oromia Regional State, Ethiopia," Journal of Ethnobiology and Ethnomedicine, vol. 11, article 25, 2015.

[14] National Research Council (US) Committee for the Update of the Guide for the Care and Use of Laboratory Animals, Guide for the Care and Use of Laboratory Animals, National Academies Press (US), Washington DC, USA, 8th edition edition, 2011.

[15] OECD, Test No. 425: Acute Oral Toxicity: Up-and-Down Procedure, OECD Publishing, 2008.

[16] V. Arul, S. Miyazaki, and R. Dhananjayan, "Studies on the antiinflammatory, antipyretic and analgesic properties of the leaves of Aegle marmelos Corr.," Journal of Ethnopharmacology, vol. 96, no. 1-2, pp. 159-163, 2005.

[17] C. S. Shreedhara, V. P. Vaidya, H. M. Vagdevi, K. P. Latha, K. S. Muralikrishna, and A. M. Krupanidhi, "Screening of Bauhinia purpurea Linn. for analgesic and anti-inflammatory activities," Indian Journal of Pharmacology, vol. 41, no. 2, pp. 75-79, 2009.

[18] D. Le Bars, M. Gozariu, and S. W. Cadden, "Animal models of nociception," Pharmacological Reviews, vol. 53, no. 4, pp. 597652, 2001

[19] R. D. Yadav, S. K. Jain, S. Alok, and S. Sharma, "Analgesic activity of ethanolic extract of Pongamia pinnata Linn. leaves," Der Pharmacia Lettre, vol. 3, no. 5, pp. 179-182, 2017.

[20] A. G. Neto, J. M. L. C. Costa, C. C. Belati et al., "Analgesic and anti-inflammatory activity of a crude root extract of Pfaffia glomerata (Spreng) Pedersen," Journal of Ethnopharmacology, vol. 96, no. 1-2, pp. 87-91, 2005.

[21] P. R. Dash, M. S. Rana, and M. S. Ali, "Investigation of analgesic and cytotoxic activities of ethanol extract of Commelina appendiculata," Journal of Pharmacognosy and Phytochemistry, vol. 4, pp. 53-59, 2015.

[22] C. A. Winter, E. A. Risley, and G. W. Nuss, "Carrageenininduced edema in hind paw of the rat as an assay for antiiflammatory drugs," Proceedings of the Society for Experimental Biology and Medicine, vol. 3, pp. 544-547, 1962.

[23] M. A. Rahman, J. S. Chakma, S. Islam, M. S. Rana, and N. U. Ahmed, "Analgesic and anti-inflammatory effect of Clausena suffruticosa root extract in animal model," Journal of Scientific Research, vol. 3, 2011.

[24] J. E. Okokon, A. E. Udoh, S. G. Frank, and L. U. Amazu, "Antiinflammatory and analgesic activities of Melanthera scandens," Asian Pacific Journal of Tropical Biomedicine, vol. 2, no. 2, pp. 144-148, 2012.

[25] K. Balamurugan, G. Sakthidevi, and V. R. Mohan, "Antiinflammatory activity of leaf of Melastoma malabathricum L. (Melastomataceae)," International Journal of Research in Ayurveda and Pharmacy, vol. 3, no. 6, pp. 801-802, 2012.

[26] R. Meier, W. Schuler, and P. Desaulles, "Zur Frage des Mechanismus der Hemmung des Bindegewebswachstums durch Cortisone," Experientia, vol. 6, no. 12, pp. 469-471, 1950.

[27] W. M. Barros, V. S. N. Rao, R. M. Silva, J. C. S. Lima, and D. T. O. Martins, "Anti-inflammatory effect of the ethanolic extract from Bowdichia virgilioides H. B. K. stem bark," Anais da Academia Brasileira de Ciências, vol. 82, no. 3, pp. 609-616, 2010.
[28] T. Ahmed Aziz, B. Hasan Marouf, Z. Aorahman Ahmed, and S. Abdulrahman Hussain, "Anti-inflammatory activity of silibinin in animal models of chronic inflammation," American Journal of Pharmacological Sciences, vol. 2, pp. 7-11, 2014.

[29] W. C. Evans, D. Evans, and G. E. Trease, Trease and Evans pharmacognosy, Saunders/Elsevier, Edinburgh, NY, USA, 16th edition edition, 2009.

[30] F. M. Abraham, T. Ayele, T. Reta, T. Wondmagege, and E. Tadesse, "Experimental evaluation of wound healing activity of Croton macrostachyus in rat," African Journal of Pharmacy and Pharmacology, vol. 10, no. 39, pp. 832-838, 2016.

[31] N. Thamizhselvam, S. Soumya, R. Sanjayakumar, K. Salinichandran, N. Venugopalan, and N. Jaya, "Anti-inflammatory, analgesic and antipyretic activity of methanolic extract of Cinnamomum tamala (nees) in experimental animal models," International Journal of Bioassays, vol. 1, pp. 26-29, 2012.

[32] R. A. Patil, P. M. Langade, P. B. Dighade, and Y. A. Hiray, "Antinociceptive activity of acute and chronic administration of Murraya koenigii L. leaves in experimental animal models," Indian Journal of Pharmacology, vol. 44, no. 1, pp. 15-19, 2012.

[33] É. T. De Souza, D. P. De Lira, A. C. De Queiroz et al., “The antinociceptive and anti-inflammatory activities of caulerpin, a bisindole alkaloid isolated from seaweeds of the genus Caulerpa," Marine Drugs, vol. 7, no. 4, pp. 689-704, 2009.

[34] A. Kumari, J. Rao, J. Kumari et al., "Analgesic activity of aqueous extract of citrullus lanatus peels," Advances in Pharmacology and Pharmacy, vol. 1, pp. 135-138, 2013.

[35] A. Elumalai, M. C. Eswaraiah, K. M. Lahari, and H. A. Shaik, "In-vivo screening of bougainvillea glabra leaves for its analgesic, antipyretic and anti-inflammatory activities," Asian Journal of Pharmaceutical Sciences, vol. 2, pp. 85-87, 2012.

[36] H. K. Solanki, D. A. Shah, P. M. Maheriya, and C. A. Patel, "Evaluation of anti-inflammatory activity of probiotic on carrageenan-induced paw edema in Wistar rats," International Journal of Biological Macromolecules, vol. 72, pp. 1277-1282, 2015.

[37] D. S. Khobragade, L. Rajahamsa A K, T. K. V. K. Rao, P. K. A V R, G. R. S. Reddy, and M. S. Potbhare, "Multi-model confirmatory evaluation of anti-inflammatory, analgesic and antioxidant activities of Putranjiva roxburghii wall," International Journal of Biomedical and Advance Research, vol. 4, no. 12, 2013.

[38] E. Tamaddonfard, A.-A. Farshid, K. Eghdami, F. Samadi, and A. Erfanparast, "Comparison of the effects of crocin, safranal and diclofenac on local inflammation and inflammatory pain responses induced by carrageenan in rats," Pharmacological Reports, vol. 65, no. 5, pp. 1272-1280, 2013.

[39] R. K. Singh, Vaishali, S. K. Panda et al., "Evaluation of antiinflammatory potential of Nardostachys jatamansi rhizome in experimental rodents," Journal of Coastal Life Medicine, vol. 2, no. 1, pp. 38-43, 2014.

[40] N. Sengar, A. Joshi, S. K. Prasad, and S. Hemalatha, "Antiinflammatory, analgesic and anti-pyretic activities of standardized root extract of Jasminum sambac," Journal of Ethnopharmacology, vol. 160, pp. 140-148, 2015.

[41] G. I. Anuja, P. G. Latha, V. J. Shine et al., "Antioedematous and analgesic properties of fertile fronds of Drynaria quercifolia," ISRN Inflammation, vol. 2014, Article ID 302089, 8 pages, 2014.

[42] S. Beg, S. Swain, H. Hasan, M. A. Barkat, and M. S. Hussain, "Systematic review of herbals as potential anti-inflammatory agents: Recent advances, current clinical status and future perspectives," Pharmacognosy Reviews, vol. 5, no. 10, pp. 120137, 2011. 
[43] G. Yuan, M. L. Wahlqvist, G. He, M. Yang, and D. Li, "Natural products and anti-inflammatory activity," Asia Pacific Journal of Clinical Nutrition, vol. 15, pp. 143-152, 2006.

[44] A. Salminen, M. Lehtonen, T. Suuronen, K. Kaarniranta, and J. Huuskonen, "Terpenoids: natural inhibitors of NF- $\kappa$ B signaling with anti-inflammatory and anticancer potential," Cellular and Molecular Life Sciences, vol. 65, no. 19, pp. 2979-2999, 2008.

[45] A. García-Lafuente, E. Guillamón, A. Villares, M. A. Rostagno, and J. A. Martínez, "Flavonoids as anti-inflammatory agents: implications in cancer and cardiovascular disease," Inflammation Research: Official Journal of the European Histamine Research Society, vol. 58, no. 9, pp. 537-552, 2009.

[46] M. Serafini, I. Peluso, and A. Raguzzini, "Flavonoids as antiinflammatory agents," Proceedings of the Nutrition Society, vol. 69, no. 3, pp. 273-278, 2010.

[47] A. A. Mali, D. D. Bandawane, and M. G. Hivrale, "Antiinflammatory and analgesic activities of ethyl acetate and petroleum ether fractions of Cassia auriculata Linn. leaves," Oriental Pharmacy and Experimental Medicine, vol. 13, no. 3, pp. 191-197, 2013.

[48] M. D. Jeffers, Tannins as Anti-Inflammatory Agents, Miami University, 2006.

[49] F. A. Moharram and S. M. El-Shenawy, "Antinociceptive and anti-inflammatory steroidal saponins from Dracaena ombet," Planta Medica, vol. 73, no. 10, pp. 1101-1106, 2007.

[50] H. S. Hassan, M. I. Sule, A. M. Musa, K. Y. Musa, M. S. Abubakar, and A. S. Hassan, "Anti-inflammatory activity of crude saponin extracts from five Nigerian medicinal plants," African Journal of Traditional, Complementary, and Alternative Medicines, vol. 9, pp. 250-255, 2012. 


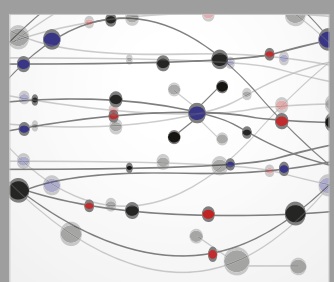

The Scientific World Journal
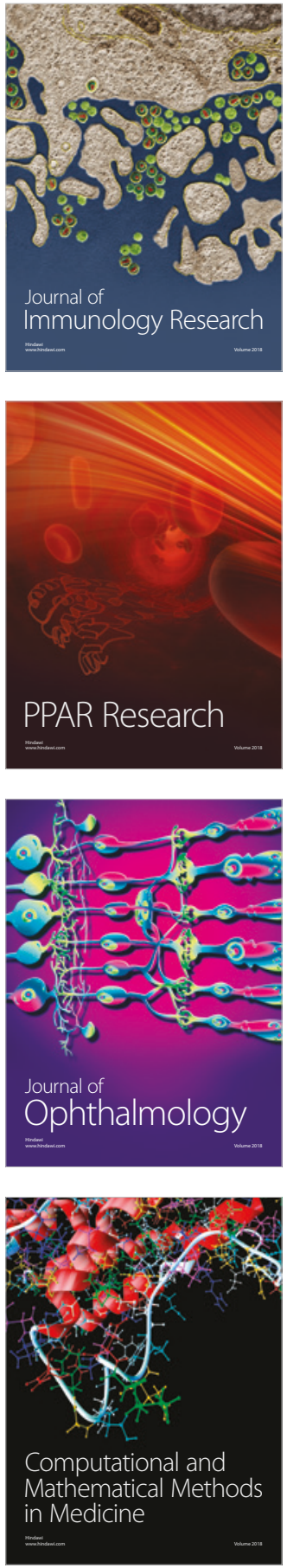

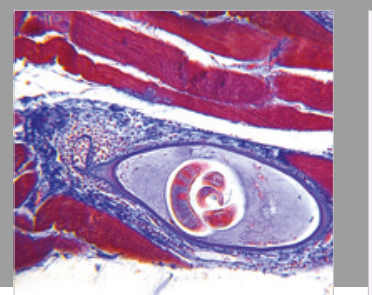

Gastroenterology Research and Practice

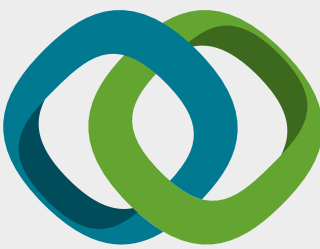

\section{Hindawi}

Submit your manuscripts at

www.hindawi.com
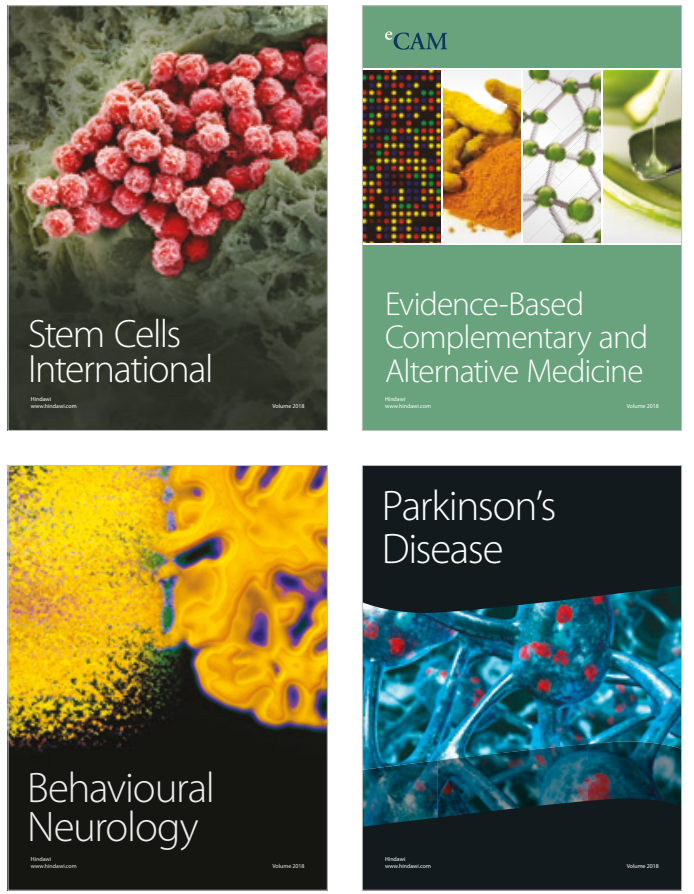

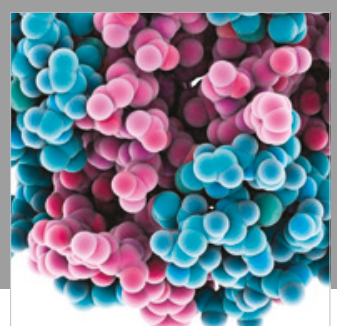

ournal of

Diabetes Research

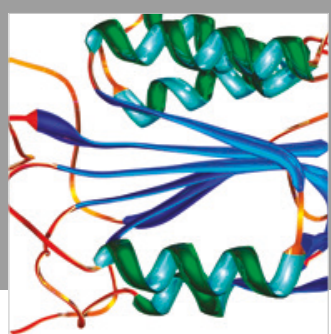

Disease Markers
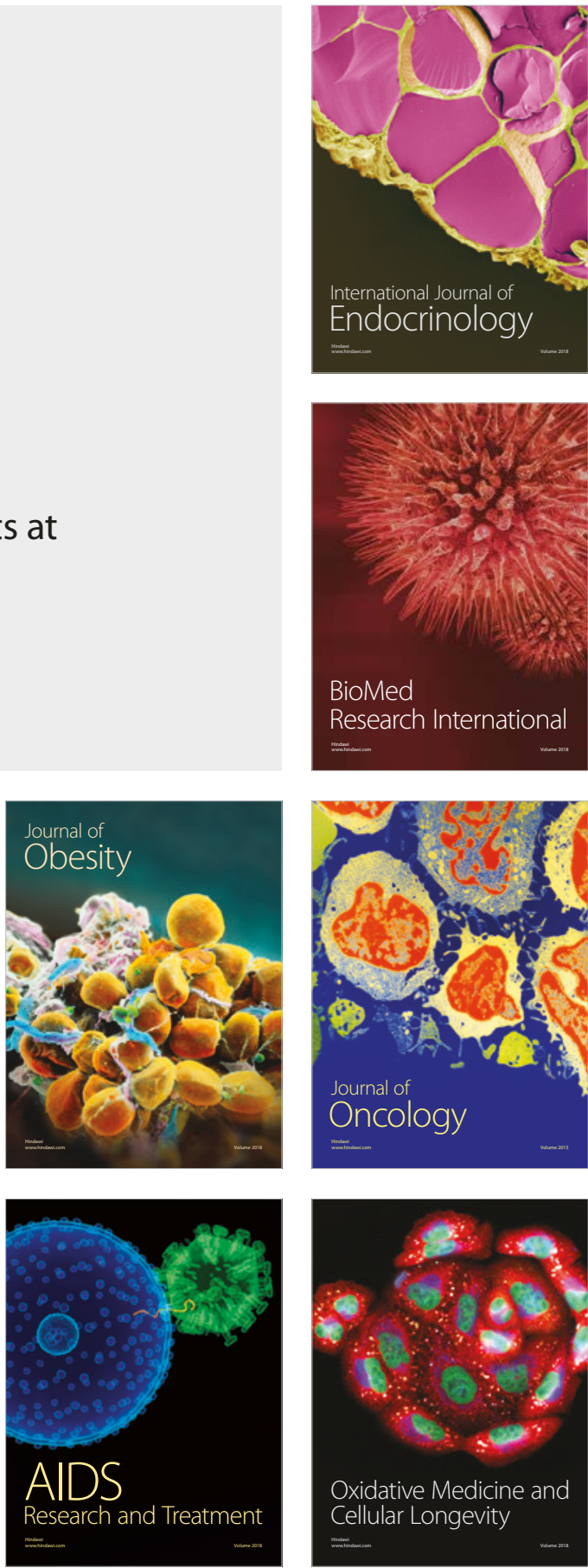